\title{
SPRAWOZDANIE Z DZIAŁALNOŚCI MIĘDZYWYDZIAŁOWEJ KATEDRY TEOLOGII KATOLICKIEJ \\ UNIWERSYTETU W BIAŁYMSTOKU \\ W ROKU AKADEMICKIM 2003/2004
}

W prezentowanym okresie sprawozdawczym (1 X 2003 - 30 IX 2004) pracownicy Międzywydziałowej Katedry Teologii Katolickiej Uniwersytetu w Białymstoku, w ramach założeń statutowych katedry jako jednostki naukowo-dydaktycznej, realizowali określony wcześniej na spotkaniach roboczych program. We współpracy z innymi jednostkami naukowymi regionu organizowali bądź brali czynny udział w konferencjach naukowych, sympozjach, sesjach i zjazdach, stawiając sobie jako cel zasadniczy propagowanie nauk teologicznych i prezentację wyników badań własnych.

Program Dni Nauki, Kultury i Sztuki zorganizowanych ku uczczeniu 25. rocznicy pontyfikatu papieża Jana Pawła II w dniach 16-19 X 2003 r. powstał i został zrealizowany wspólnym wysiłkiem MKTK, Wydziału Ar’chitektury Politechniki Białostockiej, Akademii Muzycznej im. Fryderyka Chopina w Warszawie (filia w Białymstoku), Wydziału Sztuki Lalkarskiej w Białymstoku (Akademia Teatralna im. A. Zelwerowicza w Warszawie). Otwierając obchody jubileuszu, kierownik katedry ks. bp prof. dr hab. Edward Ozorowski dn. $16 \mathrm{X}$ w auli Akademii Muzycznej zauważył, iż: „mamy okazję, przyglądając się tej niezwykłej postaci, patrzeć w tym samym kierunku, na który on nam wskazuje". „Piękno celebracji eucharystycznej” - hasło Dni Nauki, Kultury i Sztuki zaczerpnięto z encykliki Jana Pawła II „Ecclesia de Eucharistia”. W drugim dniu naukowej refleksji nad rolą i miejscem sztuki w liturgii wykład pt. „Duch liturgii Eucharystycznej" w auli Politechniki Białostockiej wygłosił bp E. Ozorowski. Oprócz udziału w wykładach i sesjach naukowych przeprowadzonych na wyższych uczelniach Białegostoku na temat piękna w liturgii i w architekturze, uczestnicy „Dni” mieli możliwość udziału w warsztatach muzyki i architektury sakralnej oraz w koncertach i spektaklach teatralnych.

Katedra Teologii Katolickiej objęła patronat i zorganizowała w dn. 10 I 2004 r., w ramach tzw. „zjazdu kolędowego”, konferencję naukową pod hasłem „Różne oblicza jednoczącej się Europy”. Spotkanie odbyło się w sali białostockiego kina „Ton” i tradycyjnie wzięli w nim udział wykładowcy i alumni Archi- 
diecezjalnego Wyższego Seminarium Duchownego w Białymstoku oraz duszpasterze i katecheci archidiecezji białostockiej. Otwierając konferencję kierownik katedry, nawiązując do hasła obrad, stwierdził m.in., iż Kościół w procesie jednoczenia się kontynentu nie stoi na uboczu przemian i uważnie śledzi jego przebieg, starając się, na miarę możliwości, sterować nim tak, by przebiegał w duchu Ewangelii. „Kościół bowiem - stwierdził bp Ozorowski jest świadom, że ta jedność nie zamyka się tylko w granicach geograficznych i nie sprowadza się do wymiany ekonomicznej”. W ramach konferencji referaty wygłosili: Biskup Polowy Wojska Polskiego, gen. dyw. bp Sławoj Leszek Głódź, przewodniczący Komisji Episkopatu Polski ds. Polonii i Polaków za granicą, biskup pomocniczy archidiecezji lubelskiej Ryszard Karpiński i Matka Generalna sióstr urszulanek, s. Jolanta Olech. Bp Głódź w referacie „Duszpasterstwo wojskowe w Europie i rejonach konfliktów zbrojnych" dość szczegółowo omówił ustrój i organizację ordynariatu polowego, zaprezentował aktualny stan ordynariatów polowych w Europie oraz rolę i zadania kapelanów wojskowych w misjach pokojowych. W referacie „Duszpasterstwo polonijne w Europie” bp Karpiński ograniczył się do prezentacji misji katolickich wśród polonii europejskiej w poszczególnych państwach, podając masę danych statystycznych powszechnie dostępnych na stronach internetowych i w istniejących opracowaniach. S. Olech, realizując w swoim wystąpieniu temat „Życie zakonne w Europie wobec zachodzących zmian politycznych”, podkreśliła znaczący wkład zakonów w budowanie współczesnego oblicza Europy „[...] we wszystkich niemal dziedzinach, od uprawy roli, rzemiosło, poprzez różne dziedziny ekonomii, szkolnictwo, naukę, sztukę, różne formy pomocy społecznej".

Z okazji 25-lecia sakry biskupiej, 40-lecia święceń kapłańskich i 30-lecia pracy w AWSD w Białymstoku kierownika MKTK, ks. bp. prof. dr. hab. E. Ozorowskiego, Katedra Teologii Katolickiej włączyła się w obchody jubileuszowe poprzez zorganizowanie w dn. 17 IV 2004 r. sesji naukowej poświęconej działalności naukowej Jubilata. W sali kina „Ton” referat nt. „W służbie Słowu” wygłosił ks. prof. dr hab. Czesław Bartnik. Rekapitulując swoje perfekcyjne pod względem merytorycznym i metodycznym, a jednocześnie przystępne w odbiorze wystąpienie, prelegent scharakteryzował pokrótce twórczość słowa i twórczość naukową bp. Ozorowskiego stwierdzając, iż aktywność naukową i posługę słowa Jubilata charakteryzuje mocna i żywa wiara religijna, realizm w przedstawianiu prawd teologicznych, które „nigdy nie są tu li tylko czysto werbalne, czy koncepcyjne”, pełna prawowierność i eklezjalność, którą Ksiądz Biskup posiadł dzięki odpowiedniemu zmysłowi prawdy i głębokiemu zakorzenieniu w tradycji, naturalność i prostota bez udziwnień i przesadnej emocjonalności, oryginalność wobiektywizmie i lakonicznych syntezach, wybitny zmysł historyczny, odpowiedzialne otwarcie ekumeniczne, dociekliwość, krytyczność, rzeczowość, syntetyczność i wreszcie - co podkreślił prof. Bartnik osobowa i językowa przejrzystość, szczerość, solidność, rzetelność. Uprzedzając zaś życzenia i gratulacje przewidziane na drugą, nieoficjalną część sesji, Prelegent pozwolił, w imieniu wszystkich zebranych, wyrazić słowa 
wdzięczności „za słowo, za naukę, za życie ewangeliczne, za całą postawę w naszych czasach, co nie jest sprawą prywatną biskupa, lecz społeczną, eklezjalną i naszą wspólną, także polską". Drugi referat wygłosił ks. prof. dr hab. Czesław Rychlicki. Już na wstępie swego wystąpienia zatytułowanego „Pasterskie posłannictwo biskupa w adhortacji apostolskiej Jana Pawła II Pastores gregis" prelegent stwierdził, iż charakter uroczystości może rodzić obawę, by jego głos nie został zrozumiany jako „chęć instruowania, a tym bardziej jakiegoś konkretyzowania obiektywnego przesłania w ściśle określonej osobie”, dlatego zaznaczył, że treść referatu odzwierciedla „obiektywne przekonanie Kościoła [...] o właściwym miejscu hierarchicznego kapłaństwa pośród ludu chrześcijańskiego, wyznaczonym przez związaną z tym kapłaństwem funkcję służebną”. Poczyniwszy takie zastrzeżenie ks. Rychlicki w swoim wystąpieniu pozostał mu wierny i konsekwentny, podkreślając fakt, iż funkcja służebna ,jako istotne zadanie biskupa została zaakcentowana w sposób wyjątkowy w adhortacji apostolskiej Pastores gregis".

$\mathrm{Z}$ okazji wspomnianego jubileuszu, z inicjatywy i przy zaangażowaniu pracowników MKTK, ukazała się drukiem praca zbiorowa pt. „W tym, który umacnia” (Białystok 2004). Cel tej publikacji wyjaśnia we wprowadzeniu jej redaktor ks. dr hab. Józef Zabielski, prof. UKSW. Pisze tam: „Jedną z form naszego uczestnictwa w tym potrójnym jubileuszu [...] jest niniejsza Księga Pamiątkowa. Jest ona wyrazem szacunku i wdzięczności, jaki Czcigodnemu Jubilatowi składa Białostocka Archidiecezja wraz z innymi bliskimi mu osobami”. Zasadniczą treść publikacji stanowią artykuły autorstwa zarówno pracowników MKTK, jak też kadry naukowej AWSD oraz osób z innych, bliskich Jubilatowi, środowisk naukowych. Publikacja ta otwiera tym samym zainicjowaną przez MKTK w minionym roku akademickim nową serię wydawniczą (pierwszy tom) pt. „Rozprawy Międzywydziałowej Katedry Teologii Katolickiej Uniwersytetu w Białymstoku".

Nawiązując do powstałego przed trzema laty, podczas zorganizowanej wspólnym wysiłkiem pracowników MKTK i Katedry Polityki Ekonomicznej i Społecznej, konferencji naukowej nt. „Człowiek-Etyka-Ekonomia” projektu analogicznej sesji, mającej być w założeniu kontynuacją, rozwinięciem i poszerzeniem problematyki wówczas dyskutowanej, wspomniane jednostki naukowe, pozostając w stałym kontakcie, zorganizowały konferencję naukowa nt. „Rodzina-Etyka-Ekonomia”. Odbyła się ona w dniach 16-18 V 2004 r. na Wigrach. Patronat nad konferencją objęli metropolita białostocki abp Wojciech Ziemba i prezydent Białegostoku Ryszard Tur. Organizatorzy postawili sobie za cel prezentację poglądów i poszukiwanie odpowiedzi na pojawiające się we współczesnej rzeczywistości problemy na styku rodzina-ekonomia. W trakcie dwudniowych obrad referaty zaprezentowało 25 prelegentów, w tym wszyscy pracownicy naukowo-dydaktyczni MKTK: bp E. Ozorowski („Nieprzemijalna wartość rodziny”), ks. J. Zabielski („Etyczne problemy życia rodzinnego”), ks. A. Skreczko („Wychowanie do życia w rodzinie”), ks. W. Michniewicz („Rodzina w Biblii”), ks. T. Kasabuła („Blaski i cienie rodziny polskiej w XVIII 
wieku”). Zaprezentowane treści pozwoliły na wstępną, ostrożną ocenę powiązań pomiędzy rodziną, etyką i gospodarką we współczesnej polskiej rzeczywistości, określenie ich jasnych i ciemnych stron z uwzględnieniem prognoz na bliższą i dalszą przyszłość, skłoniły do refleksji nad reformą i możliwościami poprawienia kondycji rodziny polskiej. Pełne, opracowane edytorsko, teksty poszczególnych referatów ukażą się drukiem w osobnej pozycji książkowej.

W roku akademickim 2003/2004 Katedra Teologii Katolickiej we współpracy z AWSD, Akcją Katolicką, Podlaskim Stowarzyszeniem Absolwentów KUL, Fundacją Edukacji i Twórczości oraz Podlaskiego Oddziału Katolickiego Stowarzyszenia „Civitas Christiana” zorganizowała drugi cykl comiesięcznych wykładów otwartych z katolickiej nauki społecznej pod hasłem „Służyć człowiekowi w społeczeństwie”. Zgodnie z przyjętą przez organizatorów formułą, wykłady skierowane były do szerokiego kręgu odbiorców, tych zwłaszcza, którzy w okresie intensywnych przemian gospodarczych, pociągających za sobą daleko idące konsekwencje natury politycznej i społecznej, pragną zapoznać się z katolicką wizją funkcjonowania człowieka jako jednostki społecznej. Wykłady wygłosili: dn. 22 X 2003 r. - prof. dr hab. Aniela Dylus nt. „Ile etyki w biznesie”, dn. 19 XI 2003 r. - ks. dr Dariusz Wojtecki nt. „Podstawy Katolickiej Nauki Społecznej”, dn. 10 XII 2003 r. - bp prof. dr hab. Edward Ozorowski nt. „Miłość należy do definicji osoby (Jan Paweł II)”, dn. 21 I 2004 r. - ks. dr Jarosław Sobkowiak nt. „Norma moralności w społeczeństwie zróżnicowanym ideologicznie”. Dn. 18 II 2004 r. wykład nt. „Chrześcijanin w polityce” wygłosił i dyskusję panelową poprowadził pracownik naukowy UKSW red. Zbigniew Borowik. W dniu 17 III 2004 r. ks. dr Jerzy Lachowicz zapoznał słuchaczy z problematyką określoną tytułem wykładu „Chrześcijanin i świat w nauce Ojców Kościoła”. Dn. 21 IV 2004 r. ks. dr hab. Józef Zabielski, prof. UKSW, w wykładzie nt. „Fenomen korupcji” poddał omawiane zjawisko ocenie etycznej. Cykl wykładów zakończył dn. 19 V 2004 r. bp dr Adam Lepa wykładem nt. „Mass media - uzależnienie czy rozwój”. Wykłady odbywały się w sali gmachu stowarzyszenia „Civitas Christiana” w późnych godzinach popołudniowych. Przebieg wykładów i nadspodziewanie wysoka frekwencja (wystąpienia prelegentów gromadziły słuchaczy w różnym wieku z niemal wszystkich środowisk regionu) utwierdziły organizatorów w przekonaniu o potrzebie ich kontynuowania w roku akademickim 2004/2005. Ów trzeci cykl serii wykładów, według wstępnych ustaleń, będzie przebiegał pod hasłem „Rodzina drogą Kościoła”. Część wygłoszonych w minionym roku sprawozdawczym tekstów w pełnym brzmieniu została opublikowana w postaci zeszytów w serii wydawniczej „Biblioteka Wykładów Otwartych z Katolickiej Nauki Społecznej” przez podlaski oddział „Civitas Christiana”, całość zaś ukaże się niebawem w zwartej pozycji książkowej.

Miniony rok sprawozdawczy był kolejnym rokiem studiów w Podyplomowym Studium Metodyczno-Katechetycznym przy UwB, powołanym do życia przez MKTK i prowadzonym przez ks. dr. hab. Adama Skreczkę. Studium umożliwia katechetom zatrudnionym w szkołach zdobycie lub uzupełnienie 
wymaganych przez Ministerstwo Edukacji Narodowej kwalifikacji i wyższych stopni specjalizacji. Kadrę dydaktyczną studium stanowią pracownicy naukowi katedry oraz wykładowcy z innych jednostek naukowo-dydaktycznych regionu.

Pracownicy naukowo-dydaktyczni MKTK prowadzą określoną statutem działalność dydaktyczną, prowadząc wykłady na UwB oraz podejmują pracę dydaktyczną poprzez wykłady, ćwiczenia, w tym seminaria naukowe, na innych uczelniach wyższych w kraju i za granicą (Wilno - Litwa). Realizując badania własne i statutowe kontynuowali prace badawcze w zakresie tych dziedzin, które stanowią obszar ich zainteresowań, współorganizowali i uczestniczyli w sympozjach, zjazdach i konferencjach naukowych dotyczących ich specjalizacji. Wynikiem tej aktywności jest dorobek piśmienniczy, obejmujący druki zwarte i artykuły o charakterze naukowym i popularnonaukowym, publikowane w czasopismach o zakresie zarówno krajowym, jak i międzynarodowym. Pełen wykaz tych publikacji jest regularnie zamieszczany m.in. na łamach „Wiadomości Kościelnych Archidiecezji Białostockiej” oraz na stronie internetowej katedry.

W październiku 2003 r. ukazał się drugi tom „Rocznika Teologii Katolickiej”, czasopisma powołanego do życia przez MKTK w 2001 r., które w zamierzeniach twórców pisma ma dokumentować dokonania naukowe pracowników katedry i zaproszonych Gości. Ostatni tom tej publikacji zawiera artykuły, materiały, recenzje i sprawozdania powstałe w roku akademickim 2002/2003.

Powoli, acz konsekwentnie, posuwają się prace nad „Słownikiem Pojęć Chrześcijańskich”, będącym wynikiem prac badawczych pracowników katedry nad językiem teologicznym.

W miarę regularne, comiesięczne, robocze spotkania pracowników MKTK umożliwiają koordynację badań własnych i statutowych, dają możliwość prezentowania ich wyników oraz służą opracowywaniu projektu prac badawczych i działalności dydaktycznej oraz zgłaszaniu, tudzież omawianiu inicjatyw katedry, popularyzujących wiedzę teologiczną w regionie. Spotkania te są wcześniej przygotowane i przebiegają według ściśle określonego przez kierownika katedry i ujętego w punkty planu. 